Full length article

\title{
RIVER ECOLOGICAL STUDY: BUILDING THE KNOWLEDGE BASE FOR VARIETY OF ASSESSMENTS SUCH AS CLIMATE CHANGE IN NEPAL
}

\author{
B.R. Jhal*, S. Gurung', K. Khatri2, B. Gurung?3, A. Thapa' and S. Acharya ${ }^{4}$ \\ 1. Department of Environmental Science and Engineering, Kathmandu University, Dhulikhel, Nepal \\ 2. Mahendra Ratna Campus, Tribhuvan University, Kathmandu, Nepal \\ 3. $277 / 15$ Krishna Dhar Marg, Maharajgunj 3, Kathmandu, Nepal. \\ 4. Balkot 1, Bhaktapur, Nepal.
}

ABSTRACT

Climate change is now universally acknowledged to be taking place across the globe. It is generally presumed that the impacts of climate change would be more severe in the country like Nepal due to its location, physiography, poverty and lack of preparedness to cope with the changes. The last reason is mainly associated with knowledge, information and ability to use technologies based on science.

The main objective of this research is to analyze and evaluate the effects of climate change by taking fish as an indicator. However, an even more important outcome is to prepare a solid foundation of fish-based information, which could be used in the future as a reference for a variety of purposes including the study of climate change. Two sets of examples, one in the tributaries of a glacial river and another in the tributary of a rain -fed river are compared in terms of fish ecological attributes to test for effects of climate change. In addition to fish-based information, this research also studies physico-chemical parameters and benthic fauna so as to build up an ecological profile of the rivers.

KEYWORDS: River ecology, electrofishing, fish assemblage, bioindicators, climate change

*Corresponding author: (Email: bibhuti@ku.edu.np)

\section{INTRODUCTION}

Climate change is now universally acknowledged by scientists, international organizations and policy makers to be a global phenomenon [1]. Nepal is no exception in experiencing the warm temperatures. Between 1977 to 1994, the country has experienced an annual temperature increase of $0.06^{\circ} \mathrm{C}$ [2]. It is generally presumed that the impacts of climate change would be more severe in a country like Nepal due to its location, physiography, poverty and lack of preparedness to cope with the changes. The last reason is mainly associated with knowledge, information and ability to use scientific technologies. Climate change study is a long term study and requires scientific information in space and time. In many sectors, Nepal either lacks primary information or is messed up with unscientific documentation of available information.

In general, Nepal has scant information on its aquatic biodiversity considering the number and volume of its water bodies, with rivers alone exceeding well past $45,000 \mathrm{~km}$ mark covering $3,95,000$ ha of surface [3]. 
Though there are a number of studies describing the extent of fish diversity $[4,5,6,7$, $8,9,10]$, the information is still scant and largely descriptive considering the size of the water resource of the country and complicated locations and physiography. New studies show that the number of fish species present in the country is increasing as it should be, to more than 200 species but the last taxonomic revision of the fish fauna lists 182 species [11]. More explorations and studies have tremendous potential to increase fish species in Nepal. However, except the work of Jha [12] most of the fish-based studies in the past do not include the effects of disturbances including those of climate change. There is even less information regarding other groups of organisms than fish in Nepal's water regime together with other vital physical and chemical accounts of water.

Although, headwaters and their tributaries are recognized as important ecosystems as freshwater resources [13, 14], biodiversity repositories [15]) and are sensitive to disturbances and are deteriorating, yet they have received very little attention [16, 17]. Climate change may have severe impacts on the climatically sensitive biota of mountain streams thereby, threatening the biodiversity and integrity of these ecosystems $[16,18]$. Moreover, headwater dynamics in glacial-fed and rain-fed rivers may vary in terms of source of origin [3], climate, biogeography [15], geology [19] and physicochemical parameters [20].

Considering the ecological importance and their role as environmental indicators including those of climate change, it is necessary to analyze and evaluate the biota of headwater systems. Therefore, this research - a part of an ongoing long-term study of the Nepalese rivers - attempts to describe two important biotic components: fish and macroinvertebrate assemblages in glacial fed (Tamor) and rain fed (Kamala) tributaries. The comparison of biotic components is supplemented by the information of on-site selected physico-chemical parameters of the water.

The main objective of this research is to analyze and evaluate the effects of climate change by taking fish as an indicator. However, an even more important outcome is to prepare a solid foundation of fish/river-based information, which can be used in the future as a reference to variety of purposes including the study of climate change. The specific objectives of this work are as follows:

1. To compare the fish assemblages in tributaries of glacial-fed Tamor River and tributaries of spring/rain-fed Kamala River.

2. To study the distribution of benthic fauna in above mentioned sections of the rivers.

3. To study selected physico-chemical parameters of water.

\section{METHODOLOGY}

\subsection{Study area}

The study was conducted in some of the tributaries of two major rivers (Tamor and Kamala) in eastern Nepal. Three tributaries of the Tamor River were selected: Mewa Khola and Maiwa Khola in Taplejung district and Hewa Khola in Panchthar district. Two tributaries of the Kamala River were Tawa Khola and Lalleri in Udaipur district. The sampling was conducted from March 17- 21, 2015. A total of eight sites were chosen for sampling (Table 1).

Table 1: Coordinates and elevation of sampling sites 


\begin{tabular}{|c|c|c|c|c|}
\hline $\begin{array}{l}\text { Site } \\
\text { name }\end{array}$ & River & $\begin{array}{l}\text { Site } \\
\text { code }\end{array}$ & $\begin{array}{l}\text { Geographical } \\
\text { coordinates }\end{array}$ & Elevation \\
\hline Maiwa & Tamor & Ml & $\begin{array}{l}\text { N } 27^{\circ} 22.064^{\prime} \\
\text { E } 087^{\circ} 37.098^{\prime}\end{array}$ & 664 \\
\hline Mewa & Tamor & M2 & $\begin{array}{l}\text { N } 27^{\circ} 22.675^{\prime} \\
\text { E } 087^{\circ} 37.617^{\prime}\end{array}$ & 666 \\
\hline Hewa & Tamor & $\mathrm{Hl}$ & $\begin{array}{l}\text { N } 27^{\circ} 10.061^{\prime} \\
\text { E } 087^{\circ} 47.321^{\prime}\end{array}$ & 629 \\
\hline Hewa & Tamor & $\mathrm{H} 2$ & $\begin{array}{l}\text { N } 27^{\circ} 09.802^{\prime} \\
\text { E } 087^{\circ} 45.560^{\prime}\end{array}$ & 550 \\
\hline Tawa & Kamala & $\mathrm{T} 1$ & $\begin{array}{l}\text { N } 26^{\circ} 59.211^{\prime} \\
\text { E } 086^{\circ} 27.743^{\prime}\end{array}$ & 330 \\
\hline Lalleri & Tawa & Ll & $\begin{array}{l}\text { N } 26^{\circ} 59.347^{\prime} \\
\text { E } 086^{\circ} 27.430^{\prime}\end{array}$ & 327 \\
\hline Tawa & Kamala & $\mathrm{T} 2$ & $\begin{array}{l}\text { N } 26^{\circ} 57.512^{\prime} \\
\text { E } 086^{\circ} 23.361^{\prime}\end{array}$ & 258 \\
\hline Tawa & Kamala & T3 & $\begin{array}{l}\text { N } 26^{\circ} 56.925^{\prime} \\
\text { E } 086^{\circ} 17.291^{\prime}\end{array}$ & 167 \\
\hline
\end{tabular}

\subsection{Field method}

Selected water quality parameters such as temperature, $\mathrm{pH}, \mathrm{DO}$ and conductivity were measured on site by using Wagtech probes. Three replicates were taken for further statistical analysis.

The method of fish sampling applied in the study was a standard electrofishing by wading method $[12,21]$, which is a scientific method accepted all over the world. This required one or more electrofishing gear and other simple accessories such as rubber boots, nets, buckets, and measuring devices. The fish sampling was done by electrofishing gear in two runs of approximately 20 minutes and the captured fish was studied for variety of fish-based characteristics such as species, abundance, length, weight and sex. The abundance of fish was measured in temporal unit called catch per unit effort (CPUE), which is expressed as number of fish per10 minutes of electrofishing. The fishes were only shocked for a few seconds, just enough to gather in the net for the readings. They were returned to their natural habitat once the necessary information was collected. Fishes were identified to the species level using the widely used keys of the region $[5,7,22,23]$. A few specimens of each species were preserved in $70 \%$ ethanol, tagged, and kept at Kathmandu University, Environmental Science Laboratory for a record as type specimen.

Qualitative sampling of macroinvertebrates [24] was carried out for assessment of macroinvertebrate assemblages at each site. A one hundred meter river stretch was sampled using a hand net of mesh size $250 \mu \mathrm{m}$. Macroinvertebrates were collected from different substrates by kicking them and placing the net in front of the substrates so that macroinvertebrates drifted towards the net. Macroinvertebrates were also collected by handpicking from underneath the stones, wood and other detritus. They were placed onto a white tray, washed and carefully placed into sampling bottles containing $70 \%$ ethanol and brought to the laboratory for further investigation.

\subsection{Laboratory method}

In the laboratory, macroinvertebrates were identified up to Family level following relevant keys $[25,26,27]$.

One way ANOVA was applied to see significant variation in physico-chemical parameters between the rain-fed and glacialfed streams. A Pearson Chi-square test was also applied to see significant variation in fish assemblages between 2009 and 2015.

\section{RESULTS AND DISCUSSION}

The physico-chemical parameters for the investigated sites are summarized in Table 2. One way ANOVA revealed that $\mathrm{pH}(\mathrm{p}<0.05)$, conductivity and temperature $(p<0.01)$ showed significant variation between glacialfed and rain/spring-fed tributaries. $\mathrm{pH}$ was significantly higher in glacial-fed streams $(p<0.05) \quad$ whereas conductivity and 
temperature were significantly higher in rain/spring-fed streams $(p<0.01)$. One way ANOVA also revealed that all four parameters; temperature, $\mathrm{pH}, \mathrm{DO}$ and conductivity showed significant variation between different sites $(p<0.01)$.

Altogether 1,927 fishes were captured during the sampling period from all eight sites. They represented 4 orders, 8 families, 19 genera and 22 species. Cypriniformes had the highest number of families (4) followed by Siluriformes (2) and, Perciformes and Synbranchiformes (1 each). Cyprinidae was represented by 11 species; Nemacheilidae 3 species; Cobitidae and Sisoridae 2 species each, and Psilorhynchidae, Amblycipitidae, Channidae and Mastacembelidae 1 species each. Cyprinidae is the largest family of freshwater fishes and may account for more than $40 \%$ of the species in a watershed (28). A total of 9 and 15 fish species were recorded from glacial-fed and rain-fed streams respectively (Table 3). Table 4 recapitulates the total and average abundance (CPUE) of different species.

Overall, the fish abundance was higher for rain/spring-fed streams compared to glacial-fed streams, with highest abundance recorded at site T2 (115) followed by T3 (107), Tl (97), L 1 (92.32), H1 (52), M (37.4), H2 (24.75) and $M 2$ (19.07). In terms of species diversity, site L1 accounted for highest number of fish species (12 species) followed by T3 (11 species), T2 (10 species), T1 (9 species), H1 (8 species), M1 (7 species), H2 (6 species) and M2 (4 species) (Table 4). The total average abundance for all species was found to be 68.05, among which the abundance of $S$. beavani, L. guntea, B. vagra and S. rupecola was found to be fairly good whereas $B$. lohachata, C. latius, L. rohita, M. blythii, N. hexagonolepis, and P. sulcata were found to have low abundance. S. plagiostomus and $P$. sulcata were not recorded in the previous study [29] but were observed and found to have fair abundance in this study whereas $S$. labiatus and S. progastus were not observed in this study (Table 4). Difference in the sampling period could be the reason for this. Species like A. mangois, C. punctata and L. guntea have adaptive features which make them capable of breathing air, and can survive even in low dissolved oxygen and hypoxic conditions $[30,31]$. This could be the reason for high abundance of $L$. guntea (42.75/10 minutes) at site T2. Also, it has been observed that relatively higher diversity and abundance of fish are observed at agricultural sites because of nutrient input in water [12, 32]. G. gotyla gotyla was observed in almost all sites except at M2. This species is widely distributed in Nepal, and has been reported up to 1560 masl [12]. Altogether, 11 vulnerable species, 4 endangered species and 2 rare species were observed in this study according to threat category defined by Jha [11].

In addition, the comparison of fish assemblage of the selected streams at present and 6 years back [28] clearly shows the differences, which could be taken as the signs of climate change (Table 6). A Pearson Chi-Square Test showed the $P$ value of 0.018 regarding the variation of fish family composition of 2015 and 2009 assemblage, which means the variation is statistically significant. Moreover, the bar diagram (Figure 1) also showed the significant variation between the fish family assemblages, when the family Cyprinidae and others were compared. Fish assemblage in 2009 in the selected streams were just represented by two 
families namely Cyprinidae and Psilorhynchidae but 2015 assemblage in the same sites showed two more families namely Nemacheilidae and Sisoridae, clearly suggesting that conditions have changed in those 6 years' time and potentially could be attributed to climate change [1, 2].

Similarly, 37 families of macroinvertebrates belonging to 3 Phyla and 9 Orders were observed in the investigated sites (Figure 2). A total of 26 and 25 macroinvertebrate families were recorded from glacial-fed and rain/springfed streams respectively. However, this does not imply that same families were observed in both types of streams. Trichoptera, Ephemeroptera and Diptera represented the highest number of macroinvertebrate families (6 families each) followed by Hemiptera (4 families), Gastropoda (3 families each), Coleoptera, Decapoda and Oligochaeta (2 families each) and finally Plecoptera, Odonata and Megaloptera (1 family each) (Table 7).

Nine families were observed only in the glacial-fed streams with Trichoptera being the dominant taxa (3 families) followed by Oligochaeta (2 families each) and, Ephemeroptera, Diptera, Coleoptera and Hemiptera (1 family each). Molluscs and Crustaceans were observed exclusively in rain/spring-fed streams in this study. These taxa have been reported to be widely distributed in the lowland rivers and streams of Nepal [34]. One interesting finding was that Tabanidae, Corydalidae and Gomphidae were all found dead at site T2, however, Hydropsychidae was still alive. A key informant survey revealed that just 3 days before our arrival, fishermen upstream had released endosulfine into the river. A laboratory study carried out on Hydropsychidae had found that when the concentration of endosulfine increased Hydropsychidae spun a protective net around it, possibly for protection [35]. This could be the reason why only Hydropsychidae was found alive at the site, but the finding is yet to be confirmed.

Table 2: Selected Physico-chemical parameters for sampling sites

\begin{tabular}{|c|c|c|c|c|c|}
\hline Sites & River & $\begin{array}{c}\text { Temperature }\left({ }^{\circ} \mathrm{C}\right) \\
( \pm S D)\end{array}$ & $\begin{array}{c}\mathrm{pH} \\
( \pm S D)\end{array}$ & $\begin{array}{c}\mathrm{DO}\left(\mathrm{mgl}^{-1}\right) \\
( \pm \mathrm{SD})\end{array}$ & $\begin{array}{c}\text { Conductivity ( } \mu \mathrm{Scm} \text { - } \\
\text { 1) ( } \pm S D)\end{array}$ \\
\hline M1 & Tamor & $18.80 \pm 0.10$ & $7.50 \pm 0.30$ & $7.76 \pm 0.25$ & $57.10 \pm 1.34$ \\
\hline M2 & Tamor & 13.40 & $7.90 \pm 0.35$ & $10.05 \pm 0.05$ & $55.87 \pm 0.06$ \\
\hline H1 & Tamor & $17.77 \pm 0.25$ & $7.23 \pm 0.12$ & $8.42 \pm 0.07$ & $65.90 \pm 1.01$ \\
\hline $\mathrm{H} 2$ & Tamor & $15.13 \pm 0.12$ & $7.87 \pm 0.21$ & $9.13 \pm 0.06$ & $71.00 \pm 0.53$ \\
\hline TI & Kamala & $25.63 \pm 0.06$ & $7.17 \pm 0.06$ & $8.27 \pm 0.29$ & $314.00 \pm 1.73$ \\
\hline L1 & Kamala & $25.53 \pm 0.35$ & $7.23 \pm 0.15$ & $8.67 \pm 1.01$ & $300.67 \pm 0.58$ \\
\hline T2 & Kamala & $25.73 \pm 0.15$ & $7.37 \pm 0.06$ & $9.85 \pm 0.13$ & $315.67 \pm 1.53$ \\
\hline T3 & Kamala & 22.00 & 7.60 & $8.78 \pm 0.85$ & $402.67 \pm 0.58$ \\
\hline
\end{tabular}

Table 3: Comparison of fish species in glacial-fed and rain/spring-fed streams

Note: Bold letters mean common species found in glacial and rain fed streams 


\begin{tabular}{lll}
\hline S.N. & Fish species (Glacial-fed streams) & Fish species (Rain-fed streams) \\
\hline 1. & Barilius bendelisis & Acanthocobitis botia \\
2. & Garra gotyla gotyla & Amblyceps mangois \\
3. & Myersglanis blythi & Barilius bendelisis \\
4. & Neolissochilus hexagonolepis & Barilius vagra \\
5. & Pseudecheneis sulcata & Botia lohachata \\
6. & Psilorhynchus pseudecheneis & Channa punctatus \\
7. & Schistura rupecola & Crossocheilus latius \\
8. & Schizothorax plagiostomus & Danio rerio \\
9. & Schizothorax richardsonii & Garra gotyla gotyla \\
10. & & Labeo rohita \\
11. & & Lephidocephalichthys guntea \\
12. & & Mastacembelus armatus \\
13. & & Pethia conchonius \\
14. & & Puntius sophore \\
15. & & Schistura beavani \\
\hline
\end{tabular}

Table 4: Abundance of fish species in different sampling sites (catch/10 minutes of sampling)

\begin{tabular}{|c|c|c|c|c|c|c|c|c|c|}
\hline Fish Species & Ml & M2 & $\mathrm{Hl}$ & $\mathrm{H} 2$ & $\mathrm{Tl}$ & Ll & $\mathrm{T} 2$ & T3 & Average \\
\hline Acanthocobitis botia & & & & & & & 0.75 & 7.5 & 1.03 \\
\hline Amblyceps mangois & & & & & 8.33 & 2.00 & 7.00 & 5.75 & 2.88 \\
\hline Barilius bendelisis & & & 6.75 & & 3.67 & & & 0.25 & 1.33 \\
\hline Barilius vagra & & & & & 11.33 & 33.00 & 9.25 & 17.25 & 8.85 \\
\hline Botia lohachata & & & & & & & & 0.25 & 0.03 \\
\hline Crossocheilus latius & & & & & & 0.33 & & & 0.04 \\
\hline Channa punctata & & & & & 1.00 & 1.67 & 2.00 & & 0.58 \\
\hline Danio rerio & & & & & 12.33 & 4.33 & & & 2.08 \\
\hline Garra gotyla gotyla & 0.28 & & 5.75 & 2.00 & 1.33 & 7.33 & 5.50 & 2.00 & 3.02 \\
\hline Labeo rohita & & & & & & 0.67 & 0.50 & & 0.15 \\
\hline Lephidocephalichthys guntea & & & & & 10.67 & 7.33 & 42.75 & 19.50 & 10.03 \\
\hline Mastacembelus armatus & & & & & & 0.33 & 10.00 & 1.0 & 1.42 \\
\hline Myersglanis blythii & 0.26 & 1.70 & & & & & & & 0.24 \\
\hline Neolissochilus hexagonolepis & & & 1.25 & & & & & & 0.16 \\
\hline Pethia conchonius & & & & & & 2.00 & 1.75 & 1.00 & 0.59 \\
\hline Psilorhynchus pseudecheneis & 10.06 & 6.82 & 7.00 & 2.00 & & & & & 3.24 \\
\hline Pseudecheneis sulcata & 0.28 & & 1.25 & 0.50 & & & & & 0.25 \\
\hline Puntius sophore & & & & & 10.00 & 7.00 & & 1.00 & 2.25 \\
\hline Schistura beavani & & & & & 38.34 & 26.33 & 35.50 & 51.50 & 18.96 \\
\hline Schistura rupecula & 5.38 & & 23.75 & 7.00 & & & & & 4.52 \\
\hline Schizothorax plagiostomus & 5.32 & 4.64 & 6.00 & 12.25 & & & & & 3.53 \\
\hline Schizothorax richardsonii & 15.82 & 5.91 & 0.25 & 1.00 & & & & & 2.87 \\
\hline
\end{tabular}




\begin{tabular}{llllllllll}
\hline Grand Total & 37.4 & 19.07 & 52.0 & 24.75 & 97.0 & 92.32 & 115 & 107 & 68.05 \\
\hline
\end{tabular}

Table 5: Threat categories of sampled fish species

\begin{tabular}{|c|c|c|}
\hline SN. & Fish species & Threat category (Jha, 2006) \\
\hline 1 & Acanthocobitis botia & Vulnerable \\
\hline 2. & Amblyceps mangois & Rare \\
\hline 3. & Barilius bendelisis & Vulnerable \\
\hline 4. & Barilius vagra & Vulnerable \\
\hline 5. & Botia lohachata & Vulnerable \\
\hline 6. & Crossocheilus latius & Endangered \\
\hline 7. & Channa punctata & Vulnerable \\
\hline 8. & Danio rerio & Vulnerable \\
\hline 9. & Garra gotyla gotyla & Common \\
\hline 10. & Labeo rohita & - \\
\hline 11. & Lephidocephalichthys guntea & Vulnerable \\
\hline 12. & Mastacembelus armatus & Endangered \\
\hline 13. & Myersglanis blythii & Rare \\
\hline 14. & Neolissochilus hexagonolepis & Vulnerable \\
\hline 15. & Pethia conchonius & Vulnerable \\
\hline 16. & Psilorhynchus pseudecheneis & Endangered \\
\hline 17. & Pseudecheneis sulcata & Endangered \\
\hline 18. & Puntius sophore & Vulnerable \\
\hline 19. & Schistura beavani & Common \\
\hline 20. & Schistura rupecola & Fairly common \\
\hline 21. & Schizothorax plagiostomus & - \\
\hline 22. & Schizothorax richardsonii & Vulnerable \\
\hline
\end{tabular}

Table 6: Comparison of fish species in glacial-fed streams in time-scale

\begin{tabular}{lllcc}
\hline S.N. & \multicolumn{1}{c}{ Fish species } & Fish Family & $\begin{array}{c}\text { Previous study } \\
\text { (2009) }\end{array}$ & $\begin{array}{c}\text { Current study } \\
\text { (2015) }\end{array}$ \\
\hline 1. & Schizothorax plagiostomus & Cyprinidae & & $\checkmark$ \\
2. & Schizothorax richardsonii & Cyprinidae & $\checkmark$ & $\checkmark$ \\
3. & Schizothoraichthys labiatus & Cyprinidae & $\checkmark$ & \\
4. & Schizothoraichthys progastus & Cyprinidae & $\checkmark$ & $\checkmark$ \\
5. & Garra annandalei & Cyprinidae & $\checkmark$ & $\checkmark$ \\
6. & Garra gotyla gotyla & Cyprinidae & & $\checkmark$ \\
7. & Schistura rupecola & Nemacheilidae & & $\checkmark$ \\
8. & Psilorhynchus pseudecheneis & Psilorhynchidae & $\checkmark$ & $\checkmark$ \\
9. & Myersglanis blythi & Sisoridae & & $\checkmark$ \\
10. & Pseudecheneis sulcata & Sisoridae & & \\
11. & Neolissochilus hexagonolepis & Cyprinidae & & $\checkmark$ \\
\hline
\end{tabular}




\begin{tabular}{llll}
\hline 12. & Barilius barila & Cyprinidae & $\checkmark$ \\
13. & Barilius bendelisis & Cyprinidae & $\checkmark$ \\
14. & Barilius shacra & Cyprinidae & $\checkmark$ \\
\hline
\end{tabular}

Table 7: Comparison of macroinvertebrate taxa in glacial fed and rain-fed streams

Note: Bold letters mean common species found in glacial and rain fed streams

\begin{tabular}{|c|c|c|}
\hline S.N. & $\begin{array}{l}\text { Macroinvertebrate Family (Glacial-fed } \\
\text { streams) }\end{array}$ & Macroinvertebrate Family (rain-fed streams) \\
\hline 1. & Perlidae & Perlidae \\
\hline 2. & Heptageniidae & Heptageniidae \\
\hline 3. & Baetidae & Baetidae \\
\hline 4. & Caenidae & Caenidae \\
\hline 5. & Ephemeridae & Ephemerellidae \\
\hline 6. & Ephemerellidae & Leptophlebidae \\
\hline 7. & Corydalidae & Corydalidae \\
\hline 8. & Stenopsychidae & Hydropsychidae \\
\hline 9. & Hydropsychidae & Glossosomatidae \\
\hline 10. & Uenoidae & Philopotamidae \\
\hline 11. & Brachycentridae & Gomphidae \\
\hline 12. & Glossosomatidae & Tabanidae \\
\hline 13. & Gomphidae & Chironomidae \\
\hline 14. & Tabanidae & Simuliidae \\
\hline 15. & Limoniidae & Limoniidae \\
\hline 16. & Simuliidae, & Vellidae \\
\hline 17. & Chironomidae & Gerridae \\
\hline 18. & Dolichopodidae & Nepidae \\
\hline 19. & Blephariceridae & Gomphidae \\
\hline 20. & Naucoridae & Psephenidae \\
\hline 21. & Elmidae & Lymnaeidae \\
\hline 22. & Gerridae & Thiaridae \\
\hline 23. & Hirudinea & Planorbidae \\
\hline 24. & Naididae & Potamidae, \\
\hline 25. & Unidentified & Decapoda(Shrimp) \\
\hline 26. & & Unidentified \\
\hline
\end{tabular}




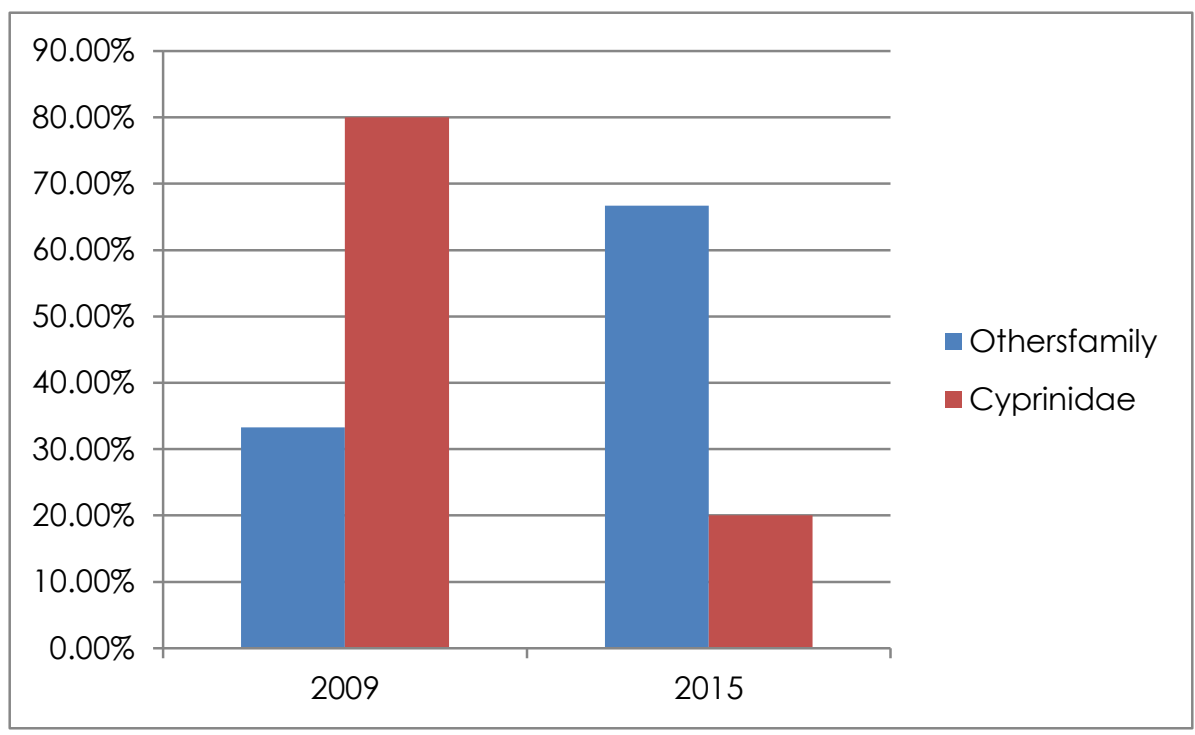

Figure 1: Bar diagram showing the comparison of fish families between 2009 and 2015

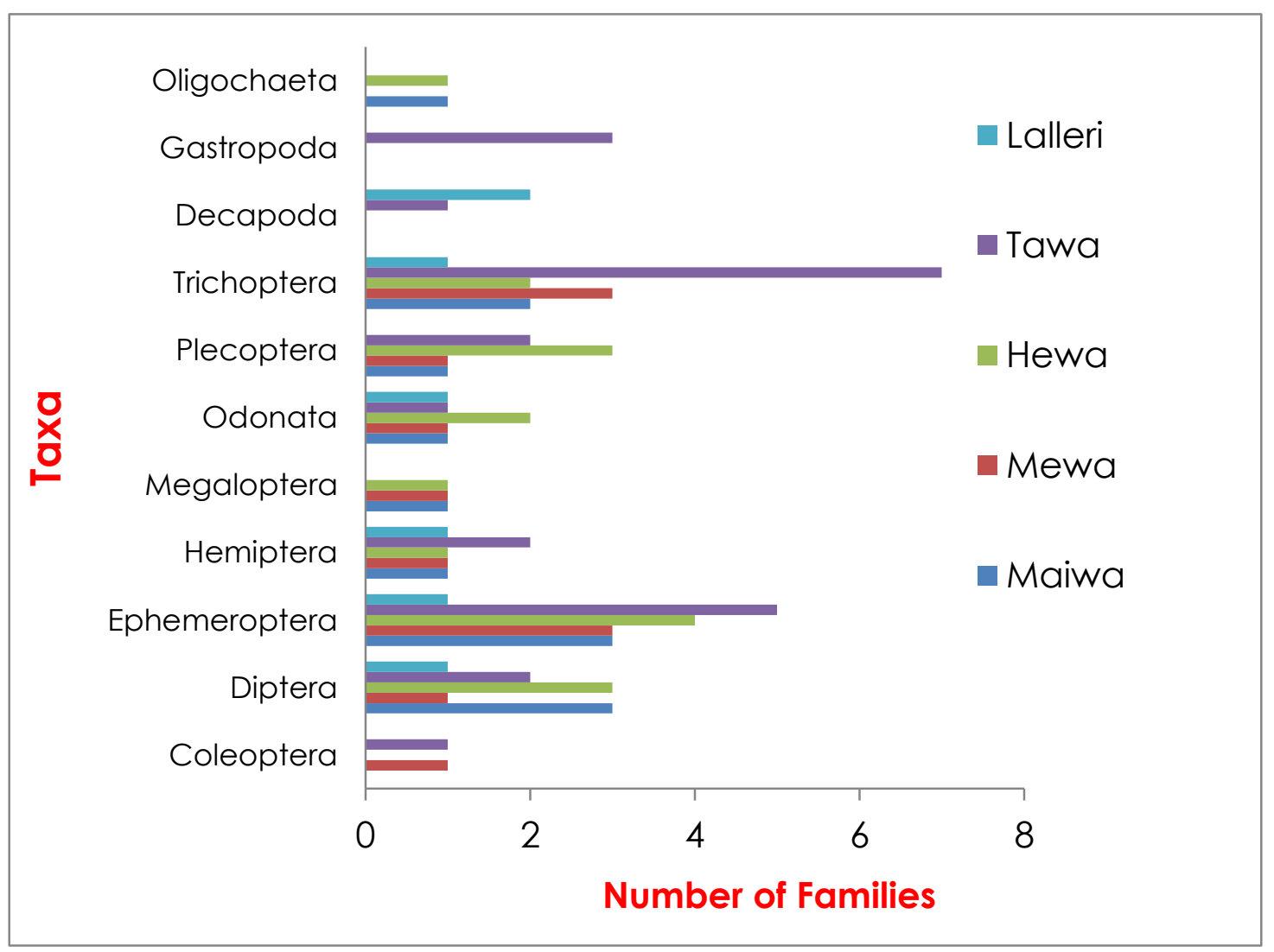

Figure 2: Macroinvertebrate Taxa with number of families observed during study period

\section{CONCLUSION}

The results of this study provide baseline information on the structure and composition of fish and macroinvertebrate communities across the two types of headwater tributaries for future studies. Both, diversity and abundance of fish species was lower in glacial-fed streams than in rain/spring-fed 
streams. The glacial-fed streams supported species preferring cool water with fast-tomoderate flow such as $S$. richardsonii, $P$. pseudecheneis, N. hexagonolepis, S. rupecola whereas warm-water species such as $D$. rerio, L. guntea, M. armatus, B. vagra, P. sophore were recorded from rain/spring-fed streams. G. gotyla gotyla was found to be more pervasive in the present study. Comparison of fish assemblage in some streams in the past and present clearly showed the signs and symptoms of climate change.

Likewise, $\quad 37$ families of macroinvertebrates were recorded from all sites. Trichoptera, Ephemeroptera and Diptera dominated most of these streams. 9 taxa were recorded only in glacial-fed streams including Stenopsychidae, Uenoidae and Oligochaetes while Molluscs and Crustaceans were observed only in the rain/spring-fed streams. In terms of physico-chemical parameters, $\mathrm{pH}$ was found to be significantly higher in glacialfed streams $(p<0.05)$ whereas conductivity and temperature were significantly higher in rain/spring-fed streams $(p<0.01)$. Thus, variation was observed in terms of fish and macroinvertebrate assemblages as well as physico-chemical parameters in the glacialfed and rain -fed headwater tributaries. Moreover, this research has tried to apply a holistic approach to study the river systems by studying physico-chemical parameters, macroinvertebrates and fish, and surely the outcome of this research will act as a reference for the future studies in climate change and related topics, and show the need to extend such research to all water bodies of Nepal.
Acknowledgements: We would like to acknowledge the contribution of Kathmandu University (KU), Nepal Academy of Science and Technology (NAST), The Climate Change Research Grant Programme (CCRGP), Asian Development Bank (ADB), the local people and institutions, and the entire team member in this research work and subsequent publications. We would also like to acknowledge Dr. Rabindra Kayastha for his help in the data analysis and statistics.

\section{References}

[1] IPCC, 2007. Climate Change 2007: The Physical Science Basis. Contribution of Working Group I to the Fourth Assessment Report of the Intergovernmental Panel on Climate Change [S. Solomon, D. Qin, M. Manning, Z. Chen, M. Marquis, K.B. Averyt, M. Tignor and H.L. Miller (eds.)]. Cambridge University Press, Cambridge, United Kingdom and New York, NY, USA, pp. 996 (2007).

[2] A. B. Shrestha, C.P. Wake, P.A. Mayewski, and J.E. Dibb. Maximum temperature Trends in the Himalaya and its vicinity: An analysis based on Temperature Records from Nepal for the Period of 1971-94. Journal of Climate. American Meteorological Society, 12 (1999) 2775-2786.

[3] Khanal, S., Effects of Human Disturbances in Nepalese Rivers on the Benthic Invertebrate Fauna .Ph.D. Thesis, University of Agricultural Sciences (BOKU). Vienna, Austria, (2001)

[4] K.G. Rajbanshi, A general bibliography on fish and fisheries of Nepal, Royal Nepal Academy, (1982).

[5] K.G Rajbanshi, Zoogeographical distribution and the status of cold water fishes of Nepal, Proceeding of symposium on cold water fish 
species in the Trans-Himalayan region, Kathmandu, Nepal (2001).

[6] P.K. Talwar and A.G. Jhingran, Inland fishes of India and adjacent countries, vol. 1, Oxford and IBH Publishing Company Pvt. Ltd., (1991)

[7] T.K. Shrestha. Resource ecology of the Himalayan waters, Curriculum Development Center, Tribhuvan University, Kathmandu, Nepal, (1990)

[8] J. Shrestha, Fishes, fishing implements and methods of Nepal, Smt. M.D. Gupta, Lalitpur colony, Lashkar (Gwalior), India, (1994).

[9] J. Shrestha, Coldwater fish and fisheries in Nepal. In Petr, T. (Eds),: Fish and fisheries at higher altitudes. Asia. FAO Fish. Tech. Pap. No. 385. FAO, Rome, (1999) 13-40.

[10] D.B. Swar, The status of cold water fish and fisheries in Nepal and prospects of their utilization for poverty reduction, Directorate of fisheries development, Central fisheries building, Balaju, Kathmandu, Nepal, (2001).

[11] J. Shrestha, Taxonomic revision of fishes of Nepal, in Jha P.K. et al., (Ed.), Environment and Agriculture: Biodiversity, Agriculture and Pollution in South Asia, p171-180, Ecological Society (ECOS), Kathmandu, Nepal (2001).

[12] B. R. Jha, Fish ecological studies and its application in assessing ecological integrity of rivers in Nepal. Ph. D. Thesis, Kathmandu University, Nepal. Agricultural University (BOKU), Vienna, Austria, (2006).

[13] M. Wipfli, J. Richardson, R. Naiman, Ecological linkages between headwaters and downstream ecosystems: Transport of organic matter, invertebrates, and wood down headwater channels. American Water Resources Association, 43 (2007) 72-85.

[14] L. Silveri, Plecoptera in Trentino: Distribution and Ecology. Ph.D. thesis, University of Parma. Italy, (2008)
[15] J. Meyer, D. Strayer, J. Wallace, S. Eggert, G. Helfman, N. Leonard, The contribution of headwater streams to biodiversity in river networks. American Water Resources Association, 43 (2007) 86-103.

[16] D. Jacobsen, A. Milner, L. Brown, O. Dangles, Biodiversity under threat in glacier-fed river systems, Nature Climate Change, 2 (2012) 361-364.

[17] M. Callanan, J. Baars, M. Kelly-Quinn, Macroinvertebrate communities of Irish headwater streams: contribution to catchment biodiversity. Biology And Environment: Proceedings Of The Royal Irish Academy, 114B (2014) 143-162.

[18] R. Tachamo-Shah, S. Sharma, P. Hasse, S. Jahnig, S. Pauls, The climate sensitive zone along an altitudinal gradient in central Himalayan rivers: A useful concept to monitor climate change impacts in mountain regions. Climate Change, 132 (2015) 265-278.

[19] R. Storey, S. Parkyn, M, Neale, T. Wilding, G, Croker, Biodiversity values of small headwater streams in contrasting land uses in the Auckland region. New Zealand Journal Of Marine And Freshwater Research, 45 (2011) 231-248.

[20] J. Olafsson, G. Gislason, H. Aoalsteinsson, Icelandic running waters; anthropological impact and their ecological status. TemaNord, 266 (2002) 86-88.

[21] C.M. Sharma and B.R. Jha, Spatial and Temporal Distribution of Fish Assemblage in Indrawati Sub-Basin. WWF, Nepal (Agreement \# WL47) (2012).

[22] F. Day, Fishes of India being a natural history of the fishes known to inhabit the seas and freshwaters of India, Burma and Ceylon, Vols. I and II. Today and Tomorrow book Agency, New Delhi. (1878). 
[23] K.C Jayaram, The Fresh Water Fishes of Indian Region. Narendra Publishing House, Delhi, India (1999).

[24] M. Barbour, J. Gerritsen, B. Snyder, J. Stribling, Rapid Bioassessment Protocols for Use in Streams and Wadeable Rivers: Periphyton, Benthic Macroinvertebrates and Fish. Washington, D.C.: U.S. Environmental Protection Agency, Office of Water (1999).

[25] R. Merritt and W. Cummins, An introduction to the aquatic insects of North America. Dubuque, lowa: Kendall/Hunt (1996).

[26] G. Wolfman, I. Sivec, A. Schmidt-Klobe, Key to Plecoptera. Regional Capacity Building Workshop on Macroinvertebrates' Taxonomy and Systematics for evaluating the Ecological Status of Rivers in the Hindukush-Himalayan (HKH) Region, 29th August to 9th September,2006, Kathmandu University, Nepal (2006).

[27] A. Hartmann, Field Key for selected benthic invertebrates from HKH Region. Draft version. February 2007. Trichoptera (2007).

[28] F.S. Beamish, \& S. Tongunui, Habitat characteristics of the Cyprinidae in small rivers in Central Thailand. Environmental Biology of Fishes, 76 (2006) 237-253.

[29] J. Shrestha, D. Singh, T. Saund, Fish diversity of Tamor River and its major tributaries of Eastern Himalayan Region of Nepal. Nepal Journal of Science and Technology, 10 (2009) 219-223.
[30] H. Das and A Dutta, Effects of industrial effluents on ecology of a wetland of Nalbari District, Assam with special reference to Ichthyofauna, An International Quarterly Journal of Environmental Sciences, 1 (2012) 147-153.

[31] R. Roy, M. Bahadur, S. Barat, Comparative study of antibiotic resistance profile of Enterebacteriaceae bacterial isolates from the gut of intestinal air-breathing fish, Lephidocephalichthys guntea and its habitat, International Journal of Science and Research, 4 (2013) 2565-2569.

[32] T. Crail, J. Gottgens, A. Krause, Fish community response to evolving channel complexity in an agricultural headwater system. Journal of Soil and Water Conservation, 66 (2011) 295-302.

[33] D. Infante, J, Allan, S. Linke, Relationship of fish and macroinvertebrate assemblages to environmental factors: Implications for community concordance, Hydrobiologia, 623 (2009) 87-103.

[34] H. Nesemann and S. Sharma, Distribution of aquatic Molluscs (Gastropoda, Bivalvia) in Nepal. Poll Res., 24 (2005) 839-842

[35] P. Sharma, Effects of multiple stressors influencing River Andhi Khola and the response of macroinvertebrates Ph. D. Thesis, Kathmandu University, Nepal (2014). 